\title{
CALCIUM OXALATE CRYSTALS IN SOME PHILODENDRON SCHOTT (ARACEAE) SPECIES
}

\author{
Mągorzata Klimko, Magdalena WaWrzyńsKa, \\ JUSTYNA WILAND-SZYMAŃSKA
}

\begin{abstract}
M. Klimko, Department of Botany, Poznań University of Life Sciences, Wojska Polskiego 71 C, 60-625 Poznań, Poland, e-mail: klim@up.poznan.pl

M. Wawrzyńska, Klaudyna Potocka High School, Zmartwychwstańców 10, 61-501 Poznań, Poland, e-mail: wawrzynska@poczta.onet.pl

J. Wiland-Szymańska, Department of Plant Taxonomy, Adam Mickiewicz University in Poznań, Umultowska 89, 61-614 Poznań, Poland, e-mail: wiland@amu.edu.pl
\end{abstract}

(Received: April 25, 2016. Accepted: May 11, 2016)

\begin{abstract}
The type and distribution (locations) of calcium oxalate crystals in mature leaves of 19 taxa of Philodendron (subgenera Meconostigma, Pteromischum and Philodendron) were studied. The calcium oxalate crystals were mainly found in the form of raphides, druses, styloids and prisms. The leaves of Philodendron demonstrate the presence of five distinctive raphide crystal types (biforine, thin-walled spindle-shaped, wide cells containing a wide raphide bundle, bundles of obliquely overlapping crystal and unmodified cells with either a single crystal needle or their cluster). Styloids and druses were found in all taxa at varying frequencies. Simple prisms and variations in crystal forms were most frequently observed in the ground tissue in petioles and midribs. This study represents additional data concerning calcium oxalate crystals in Philodendron.
\end{abstract}

KEY WoRDs: Philodendron, calcium oxalate crystals, petiole, lamina, subgenera Meconostigma, Pteromischum and Philodendron

\section{INTRODUCTION}

The family Araceae comprises 2823 species in 106 genera (GOVAERTS et al. 2002). The genus Philodendron is the largest genus in the family after Anthurium (CROAT 1997). The genus is subdivided into three subgenera: Meconostigma (15 species), Pteromischum (75 species) and Philodendron (approx. 600 species) accepted worldwide (MAYO 1988, 1990, 1991, GraYUM 1990, 1996, Croat 1997, Mayo et al. 1997, Gonçalves \& Salviani 2002, SAKURAgui et al. 2005). Philodendron is one of the most important genera in the Neotropics and provides a wide variety of choice ornamental plants for horticulture (CROAT 1997). Major cultivated species include e.g. P. bipennifolium, $P$. cordatum, $P$. hederaceum, P. lacerum and P. pedatum.

The calcium oxalate crystals were defined by botanists Franceschi \& Horner (1980): (1) druses, which are spherical aggregates of crystals; (2) raphides, acicular crystals that form in bundles; (3) sty- loids, acicular crystals that form singly; (4) prisms, consisting of simple regular prismatic shapes, and (5) crystal sand, small tetrahedral crystals forming clusters.

The occurrence, specific crystal shapes and locations of these crystals are useful taxonomic characters (Genua \& Hillson 1985, Prychid \& Rudall 1999). The accumulation of calcium oxalate crystals in plant bodies has been studies for many years. However, their function in normal plant growth and development is still unclear. Calcium oxalate crystals may form in any organ or tissue within plants (Wевв 1999). They are found e.g. in roots, stems, leaves, flowers, fruit and seeds (FranCESCHI \& HoRNER 1980) as well as within epidermal (ZINDLER-Frank 1975), ground (HORNER \& WhiTmoyer 1972) and vascular tissues (WANG et al. 1994). Calcium oxalate is often formed in idioblasts, i.e. cells that develop in isolation, with the structure or content distinct from surrounding cells (Foster 1956). The formation of cal- 
cium oxalate crystals in crystal idioblasts is affected by the availability of calcium ions (ZINDLER-FrANK 1975, FranCESCHI \& HorNer 1980, BorCHert 1984).

The presence of idioblastic cells bearing calcium oxalate raphide crystals is the defining character for Araceae (PrYchid \& Rudall 1999, KeATING 2002, 2004a, b). In other instances, crystals may develop in defined groups of cells, as e.g. in files of bundle sheath cells (BORCHERT 1984) or in a single layer of the seed coat (WebB \& ARnotT 1982). Less often, entire tissues such as the endosperm (SPITZer \& LotT 1982) or leaf epidermis (BRUBAKeR \& Horner 1989) accumulate calcium oxalate in every cell or in a majority of cells (WeвB 1999). In Philodendron stylar raphides are diagnostic features distinguishing three subgenera: in subg. Meconostigma stylar raphides are concentrated around stylar canals, in subg. Pteromischum stylar raphides are abundant, while in subg. Philodendron they are absent or rare (GRAYum 1996). Grooved raphides are found in Araceae and represent a significant apomorphy in Araceae (PRYCHID \& RUDALL 1999), while biforines are found only among unisexual flowered genera (KeAting 2004a). Idioblastic cells in Araceae were first mentioned in the description of biforines by TURPIN (1836). Araceae is the only family in which all tree main crystal types are recorded (raphides, drusese and styloids), PRYCHID \& RUdALL (1999). Since then, various systematic accounts of raphides have been published (SolEREDER \& Mayer 1928, Franceschi \& Horner 1980, Genua \& Hillson 1985, Keating 2003, 2004a, b). There are very few literature reports on calcium oxalate crystal in species of Philodendron (Croat 1997, KeAting 2003, 2004a, Kuimko et al. 2014). Calcium oxalate exists in two chemical forms, the monohydrate and the dihydrate, and both of these are found in plants. The monohydrate form is more stable and is more commonly found in plants than the dihydrate (FreYWyssLing 1981, WebB 1999).

The purpose of this study is to provide additional information on the occurrence, type and distribution of the calcium oxalate crystal in petioles and laminas of 19 taxa belonging to the genus Philodendron.

\section{MATERIAL AND METHODS}

For this study 18 species and one variety were examined (Table 1). Samples were obtained from the greenhouses of the Botanical Garden in Poznan (Poland) (BG-AMU). We included taxa from three subgenera of Philodendron (Meconostigma, Pteromischum and Philodendron). For the subgenus Philodendron, representatives from five of the nine sections recognised by Сводт (1997) were included (Table 1). For anatomical studies living material was preserved in $70 \%$ alcohol. Transverse sections of $50 \mu \mathrm{m}$ in thickness were prepared with a microtome (Leitz). Ten sections were taken from the middle parts of each petiole and lamina. All the sections were embedded in glycerine-gelatine and examined under an Olympus BX 43 light microscope with a camera lucida. Thus, slides were prepared and used to describe and measure characters of calcium oxalate crystals (Tables 2-4), the length and width of raphide bundles and the length and width of cells (idioblast) to the length and width of crystals close-packed ratio. The classification of raphide crystals follows that of Turpin (1836) and Keating (2004a).

Table 1. Philodendron specimens sed in this study (* now called sec. Macrobelium according to SAKURAGUI et al. 2005)

\begin{tabular}{|c|c|c|c|}
\hline \multirow{2}{*}{ Taxa } & \multirow{2}{*}{ Voucher information } & \multicolumn{2}{|c|}{ Taxonomy } \\
\hline & & subgenus & section \\
\hline Philodendron bipinnatifidum Schott ex Engl & I-I005-005-0000-6991-4010 & Meconostigma & \\
\hline P. surinamense Schott ex Engl & I-I005-002-0000-6995-2279 & Pteromischum & Fruticosa \\
\hline P. crassinervium Lindl & I-I005-002-0000-6990-2791 & Philodendron & Baursia \\
\hline P. melanochrysum Linden et Andre & I-I005-002-0000-6994-3999 & Philodendron & Philodendron \\
\hline P. ornatum Schott & I-I005-002-0000-6964-0233 & Philodendron & Philodendron \\
\hline P. hederaceum (Jacq.) Schott var. hederaceum & I-I005-002-0000-6991-1687 & Philodendron & Philodendron \\
\hline P. hederaceum var. oxycardium (Schott) Croat & I-I005-002-0000-6002-3997 & Philodendron & Philodendron \\
\hline P. bipennifolium Schott & I-I005-002-0000-6991-0616 & Philodendron & *Calostigma \\
\hline P. domesticum G.S.Bunting & I-I005-002-0000-6998-2453 & Philodendron & ${ }^{*}$ Calostigma \\
\hline P. cordatum (Vell.) Kunth & I-I005-002-0000-6991-2609 & Philodendron & ${ }^{*}$ Calostigma \\
\hline P. erubescens K. Koch et Augustin & I-I005-002-0000-6979-1543 & Philodendron & *Calostigma \\
\hline P. imbe Schott ex Endl. & I-I005-002-0000-6979-2234 & Philodendron & ${ }^{*}$ Calostigma \\
\hline P. martianum Endl. & I-I005-002-0000-6960-2474 & Philodendron & *Calostigma \\
\hline P. microstictum Standl. et L.O.Williams & I-I005-002-0000-6993-2466 & Philodendron & ${ }^{*}$ Calostigma \\
\hline P. pedatum (Hook) Schott & I-I005-002-0000-6992-0784 & Philodendron & Schizophyllum \\
\hline P. squamiferum Poepp. & I-I009-002-0000-6979-2246 & Philodendron & Schizophyllum \\
\hline P. angustisectum Engl. & I-I007-002-0000-6996-2369 & Philodendron & Polytomium \\
\hline P. lacerum (Jacq.) Schott & I-I005-002-0000-6988-2577 & Philodendron & Polytomium \\
\hline P. pinnatifidum (Jacq.) Schott & I-I005-002-0000-6959-2440 & Philodendron & Polytomium \\
\hline
\end{tabular}


Table 2. Location and morphometric features of druses $(\mu \mathrm{m})$ in the transverse section (T.S.) of petiole of Philodendron

\begin{tabular}{|c|c|c|c|c|c|}
\hline Taxa & Hypodermis & Collenchyma & Chlorenchyma & Parenchyma & $\begin{array}{l}\text { Around intercellu- } \\
\text { lar spaces }\end{array}$ \\
\hline Philodendron bipinnatifidum & $25.1 \times 25.7$ & & $31.9 \times 28.3$ & $54.8 \times 49.3$ & $38.4 \times 40.3$ \\
\hline P. surinamense & & $21.1 \times 18.4$ & & $45.5 \times 40.4$ & \\
\hline P. crassinervium & $25.9 \times 24.5$ & & $34.7 \times 20.3$ & $49.8 \times 46.4$ & $52.6 \times 43.3$ \\
\hline P. melanochrysum & $43.3 \times 48.9$ & & & $30.8 \times 39.5$ & \\
\hline P. ornatum & $33.1 \times 34.1$ & & & $46.9 \times 52.1$ & \\
\hline P. hederaceum var. hederaceum & $24.9 \times 25.4$ & & $33.9 \times 33.2$ & $46.6 \times 41.2$ & $32.9 \times 28.6$ \\
\hline P. hederaceum var. oxycardium & $22.5 \times 28.5$ & $26.0 \times 30.3$ & $31.3 \times 32.2$ & $33.7 \times 33.7$ & $21.6 \times 22.5$ \\
\hline P. bipennifolium & $23.9 \times 27.8$ & $22.2 \times 31.5$ & & $36.3 \times 36.7$ & $36.9 \times 35.7$ \\
\hline P. domesticum & $37.7 \times 36.4$ & $37.9 \times 52.1$ & $32.0 \times 25.6$ & $35.0 \times 33.1$ & $34.3 \times 33.5$ \\
\hline P. cordatum & $32.9 \times 28.8$ & & & $39.3 \times 34.9$ & $49.0 \times 43.1$ \\
\hline P. erubescens & & $26.5 \times 27.6$ & $35.7 \times 32.3$ & & $37.9 \times 36.2$ \\
\hline P. imbe & $29.7 \times 26.3$ & $28.1 \times 26.0$ & $32.3 \times 35.6$ & & $33.6 \times 35.5$ \\
\hline P. martianum & $31.2 \times 30.3$ & & $40.4 \times 40.3$ & $49.9 \times 48.8$ & $35.1 \times 38.1$ \\
\hline P. microstictum & & $26.9 \times 25.2$ & & $38.2 \times 34.7$ & $43.9 \times 42.3$ \\
\hline P. pedatum & $27.5 \times 29.8$ & $36.8 \times 41.5$ & & $38.2 \times 41.8$ & $34.6 \times 32.8$ \\
\hline P. squamiferum & $33.1 \times 33.3$ & $32.7 \times 33.8$ & & $37.9 \times 40.1$ & $40.3 \times 43.5$ \\
\hline P. angustisectum & $23.4 \times 24.1$ & & & & $34.1 \times 25.6$ \\
\hline P. lacerum & & & $37.1 \times 34.9$ & $36.6 \times 33.3$ & $37.1 \times 34.9$ \\
\hline P. pinnatifidum & $20.7 \times 21.7$ & $22.8 \times 22.6$ & & & $38.4 \times 36.2$ \\
\hline
\end{tabular}

Table 3. Types and morphometric features of raphides $(\mu \mathrm{m})$ in the transverse section (T.S.) of petiole of Philodendron (T.S. transverse section)

\begin{tabular}{|c|c|c|c|c|c|c|c|c|c|}
\hline Taxa & $\begin{array}{l}\text { Biforine } \\
\text {-shaped }\end{array}$ & $\begin{array}{l}\text { Length/ } \\
\text { width } \\
\text { ratio }\end{array}$ & $\begin{array}{l}\text { Spindle - } \\
\text { shaped }\end{array}$ & $\begin{array}{l}\text { Length/ } \\
\text { width } \\
\text { ratio }\end{array}$ & Wide & $\begin{array}{l}\text { Length/ } \\
\text { width } \\
\text { ratio }\end{array}$ & $\begin{array}{l}\text { Oblique-over- } \\
\text { lapping }\end{array}$ & $\begin{array}{l}\text { Length/ } \\
\text { width } \\
\text { ratio }\end{array}$ & $\begin{array}{l}\text { No of } \\
\text { raphies in } \\
\text { T.S. }\end{array}$ \\
\hline $\begin{array}{l}\text { Philodendron } \\
\text { bipinnatifidum }\end{array}$ & $108.2 \times 47.1$ & 2.3 & $91.4 \times 46.7$ & 1.9 & $74.1 \times 67.3$ & 1.1 & $117.3 \times 73.7$ & 1.6 & $11-27$ \\
\hline P. surinamense & $107.4 \times 47.1$ & 2.3 & $79.3 \times 36.1$ & 2.2 & & & $55.2 \times 48.71$ & 1.1 & $1-5$ \\
\hline \multicolumn{10}{|l|}{ P. crassinervium } \\
\hline P. melanochrysum & & & & & & & $74.4 \times 53.8$ & 1.4 & \\
\hline P. ornatum & $123.6 \times 34.7$ & 3.5 & & & $27.9 \times 27.8$ & 1.0 & & & 1 \\
\hline \multicolumn{10}{|l|}{$\begin{array}{l}\text { P. hederaceum var. } \\
\text { hederaceum }\end{array}$} \\
\hline $\begin{array}{l}\text { P. hederaceum var. } \\
\text { oxycardium }\end{array}$ & & & $128.0 \times 35.2$ & 3.6 & & & & & $1-2$ \\
\hline P. bipennifolium & & & $152.7 \times 45.1$ & 3.1 & & & & & 1 \\
\hline P. domesticum & & & $119.9 \times 32.7$ & 3.6 & $44.9 \times 33.5$ & 1.3 & & & 2 \\
\hline P. cordatum & $125.2 \times 50.4$ & 2.5 & $96,7 \times 49.4$ & 1.9 & $52.3 \times 49.2$ & 1.1 & & & $8-21$ \\
\hline \multicolumn{10}{|l|}{ P. erubescens } \\
\hline P. imbe & & & $113.7 \times 40.6$ & 2.8 & $42.9 \times 40.4$ & 1.1 & & & $1-3$ \\
\hline P. martianum & & & $109.0 \times 37.9$ & 2.8 & & & & & 1 \\
\hline P. microstictum & & & $59.8 \times 39.5$ & 1.5 & $46.6 \times 46.0$ & 1.0 & $67.8 \times 44.2$ & 1.5 & 4 \\
\hline P. pedatum & & & $70.6 \times 50.8$ & 1.4 & $56.2 \times 55.8$ & 1.0 & & & 3 \\
\hline P. squamiferum & $129.7 \times 50.8$ & 2.5 & $135.1 \times 48.1$ & 2.8 & & & & & 2 \\
\hline P. angustisectum & $170.8 \times 43.6$ & 3.8 & $109.3 \times 50.8$ & 2.1 & $54.9 \times 54.5$ & 1.0 & & & $1-6$ \\
\hline P. lacerum & $158.1 \times 44.1$ & 3.6 & $110.0 \times 41.4$ & 2.6 & $64.8 \times 53.9$ & 1.2 & & & $3-6$ \\
\hline P. pinnatifidum & $139.3 \times 47.2$ & 2.9 & $114.3 \times 50.4$ & 2.3 & & & & & $10-20$ \\
\hline
\end{tabular}


Małgorzata Klimko, Magdalena Wawrzyńska, Justyna Wiland-Szymańska

Table 4. Types and morphometric features of raphides $(\mu \mathrm{m})$ in the transverse section (T.S.) of lamina of Philodendron

\begin{tabular}{|c|c|c|c|c|c|c|c|c|c|}
\hline Type & $\begin{array}{l}\text { Biforine } \\
\text {-shaped }\end{array}$ & $\begin{array}{c}\text { Length/ } \\
\text { width } \\
\text { ratio }\end{array}$ & $\begin{array}{l}\text { Spindle - } \\
\text { shaped }\end{array}$ & $\begin{array}{c}\text { Length/ } \\
\text { width } \\
\text { ratio }\end{array}$ & Wide & $\begin{array}{c}\text { Length/ } \\
\text { width } \\
\text { ratio }\end{array}$ & $\begin{array}{c}\text { Oblique, } \\
\text { overlapping }\end{array}$ & $\begin{array}{l}\text { Length/ } \\
\text { width } \\
\text { ratio }\end{array}$ & $\begin{array}{l}\text { No of raphi- } \\
\text { des in T.S. }\end{array}$ \\
\hline $\begin{array}{l}\text { Philodendron } \\
\text { bipinnatifidum }\end{array}$ & & & $83.0 \times 58.6$ & 1.4 & $91.4 \times 66.1$ & 1.4 & $101.8 \times 66.4$ & 1.5 & $1-2$ \\
\hline P. surinamense & & & $64.3 \times 42.7$ & 1.5 & $95.7 \times 63.7$ & 1.5 & $67.0 \times 35.3$ & 1.8 & $1-2$ \\
\hline P. crassinervium & & & $90.3 \times 31.5$ & 2.8 & & & & & $1-2$ \\
\hline P. melanochrysum & $160.3 \times 28.2$ & 5.6 & $154.9 \times 31.9$ & 4.8 & & & & & 3 \\
\hline P. ornatum & $98.9 \times 33.8$ & 2.9 & $69.7 \times 33.2$ & 1.8 & $33.1 \times 34.1$ & 0.9 & & & $1-2$ \\
\hline $\begin{array}{l}\text { P. hederaceum var. } \\
\text { hederaceum }\end{array}$ & $135.3 \times 34.2$ & 3.3 & $141.0 \times 30.7$ & 4.6 & & & & & 1 \\
\hline $\begin{array}{l}\text { P. hederaceum var. } \\
\text { oxycardium }\end{array}$ & & & $137.1 \times 39.3$ & 3.5 & & & & & $1-2$ \\
\hline P. bipennifolium & $114.0 \times 24.0$ & 4.7 & & & & & & & 1 \\
\hline P. domesticum & & & $109.2 \times 28.0$ & 3.9 & & & & & 1 \\
\hline P. cordatum & $146.3 \times 48.4$ & 3.0 & & & & & & & $1-2$ \\
\hline P. erubescens & & & $129.8 \times 35.4$ & 3.6 & & & & & 1 \\
\hline P. imbe & & & $123.5 \times 35.6$ & 3.5 & & & & & $1-3$ \\
\hline P. martianum & & & $146.6 \times 45.2$ & 3.2 & & & & & 1 \\
\hline P. microstictum & & & $106.8 \times 37.9$ & 2.8 & & & & & $1-2$ \\
\hline P. pedatum & $169.8 \times 52.8$ & 3.2 & & & & & & & $1-2$ \\
\hline P. squamiferum & $173.6 \times 59.2$ & 2.9 & $166.1 \times 46.4$ & 3.6 & & & & & 1 \\
\hline P. angustisectum & & & & & $47.8 \times 42.5$ & 1.1 & $65.4 \times 56.4$ & 1.2 & $1-2$ \\
\hline P. lacerum & & & $145.3 \times 29.5$ & 4.9 & & & & & $1-2$ \\
\hline P. pinnatifidum & & & $153.9 \times 51.3$ & 2.9 & & & & & 1 \\
\hline
\end{tabular}

\section{RESULTS AND DISCUSSION}

CALCIUM OXALATE CRYSTALS IN PETIOLES are most frequently represented by druses, styloids, prismatic crystals and raphides. Idioblasts containing druses are irregularly dispersed in the petiole tissues (Table 2). In four species they were not observed in the hypodermis, in nine in the collenchyma, in 10 in the chlorenchyma, in four in parenchyma cells and in three in the cells boarding air cavities. Druses were least numerous in $P$. surinamense, $P$. crassinervium and in $P$. imbe. In cells around intercellular spaces druses are found singly or in pairs ( $P$. erubescens), in groups of 3 (P. cordatum) or 2-3 in P. martianum. The length of the druses in the hypodermis ranges from 20.7 (P. pinnatifidum) to $43.3 \mu \mathrm{m}$ (P. melanochrysum) and their width is from 21.7 (P. pinnatifidum) to $36.4 \mu \mathrm{m}$ (P. domesticum). The length of druses in the collenchyma ranges from 21.1 (P. surinamense) to $37.9 \mu \mathrm{m}$ (P. domesticum) and their width - from 18.4 (P. surinamense) to $52.1 \mu \mathrm{m}$ (P. domesticum). The length of druses in the chlorenchyma ranges from 31.3 ( $P$. hederaceum var. oxycardium) to $40.4 \mu \mathrm{m}$ (P. martianum), while their width ranges from 20.3 (P. crassinervium) to $40.3 \mu \mathrm{m}$ (P. martianum). The length of druses in parenchyma cells ranges from 30.8 (P. melanochrysum) to $54.8 \mu \mathrm{m}$
(P. bipinnatifidum) and their width - from 33.1 ( $P$. domesticum) to $52.1 \mu \mathrm{m}$ (P. ornatum). The length of druses in cells boarding intercellular spaces ranges from 21.6 (P. hederaceum var. oxycardium) to $52.6 \mu \mathrm{m}$ (P. crassinervium), while their width ranges from 22.5 (P. hederaceum var. oxycardium) to $43.5 \mu \mathrm{m}$ (P. squamiferum). No significant differences were found in the size of druses in individual tissues (Table 2).

The petiole of Philodendron demonstrates the presence of four distinctive raphide crystal types: biforine-shaped, thin-walled spindle-shaped, wide cells, and obliquely overlapping crystal bundles (Table 3, Figs 1-20). Four types of raphides were found only in P. bipinnatifidum (Table 3, Figs 1-8). Three types were observed in $P$. surinamense, $P$. cordatum, $P$. anguisectum and P. lacerum (Table 3, Figs 9, 10, 14, 17, 18). In P. melanochrysum, P. hedreraceum var. oxycardium, $P$. bipennifolium and $P$. martianum one type of raphides, the spindle-shaped type, was recorded (Table 3 ).

The length and width of the crystal packet were not equivalent to the total length and width of the cells (idioblasts) and in a majority of the studied species this bundle was shorter than the length of the cell, except for $P$. surinamense (needles fill the entire cell, Fig. 9) and P. pinnatifidum (Fig. 20) (needles equal in length to the idioblast). In most taxa raphi- 

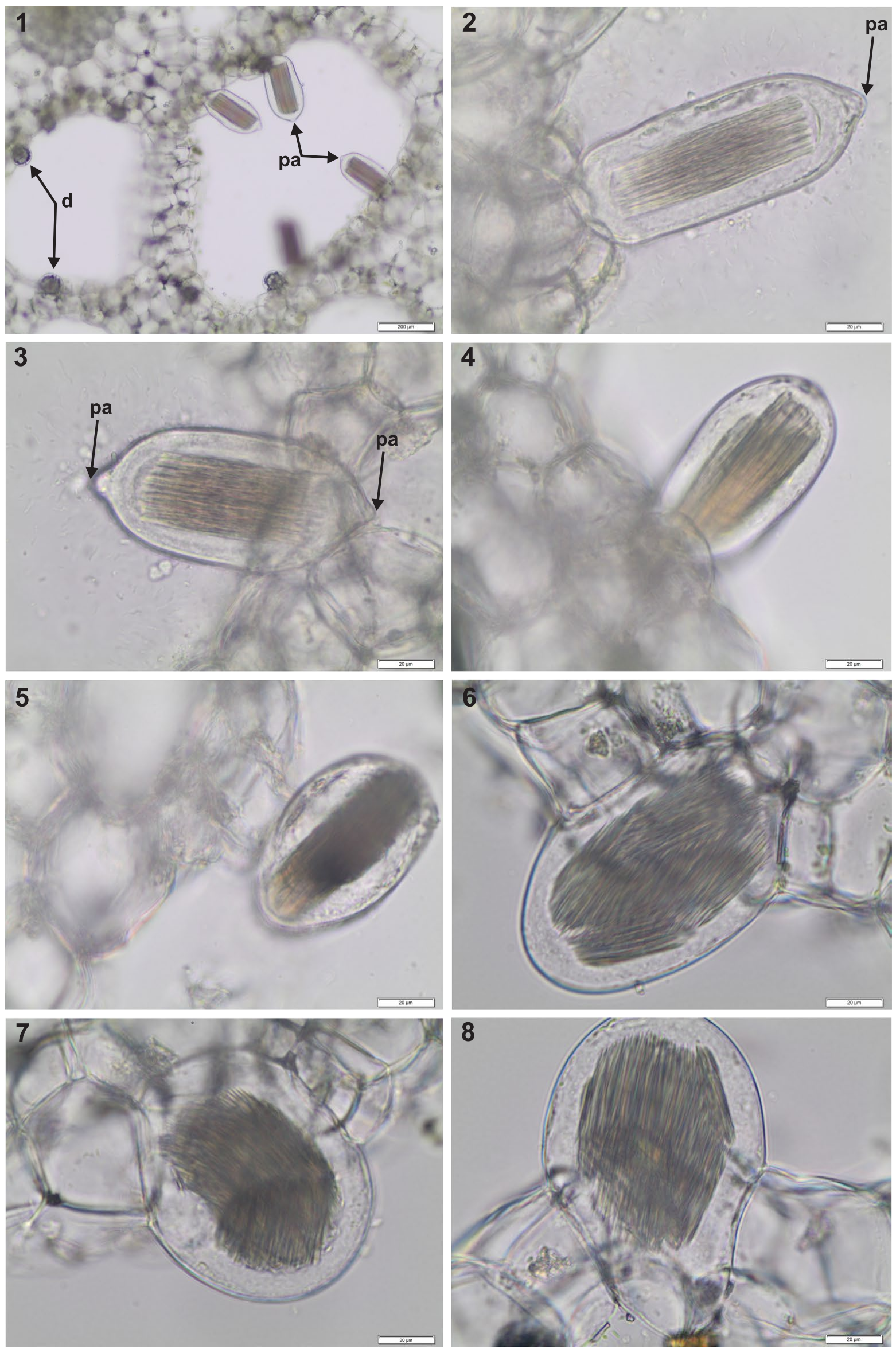

Figs 1-8. Calcium oxalate crystals in the transverse section of petiole of P. bipinnatifidum (d - druses, pa-papillae) 

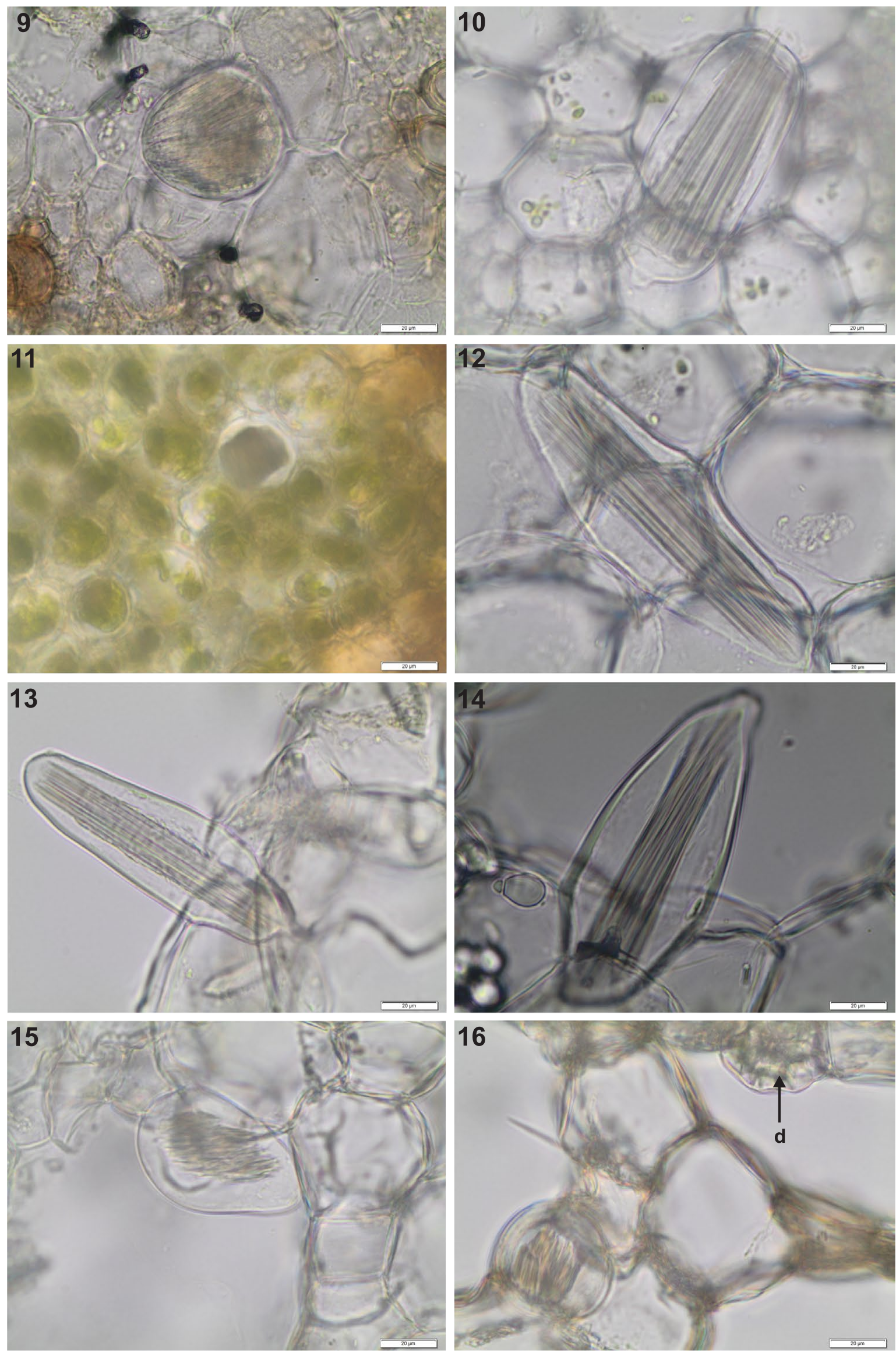

Figs 9-16. Calcium oxalate crystals in the transverse section of petiole: $9.10-P$. surinamense, $11-$ P. ornatum; $12-P$. bipennifolium, 13 - P. domesticum, $14-P$. cordatum, 15, $16-$ P. microstictum (d-druse) 

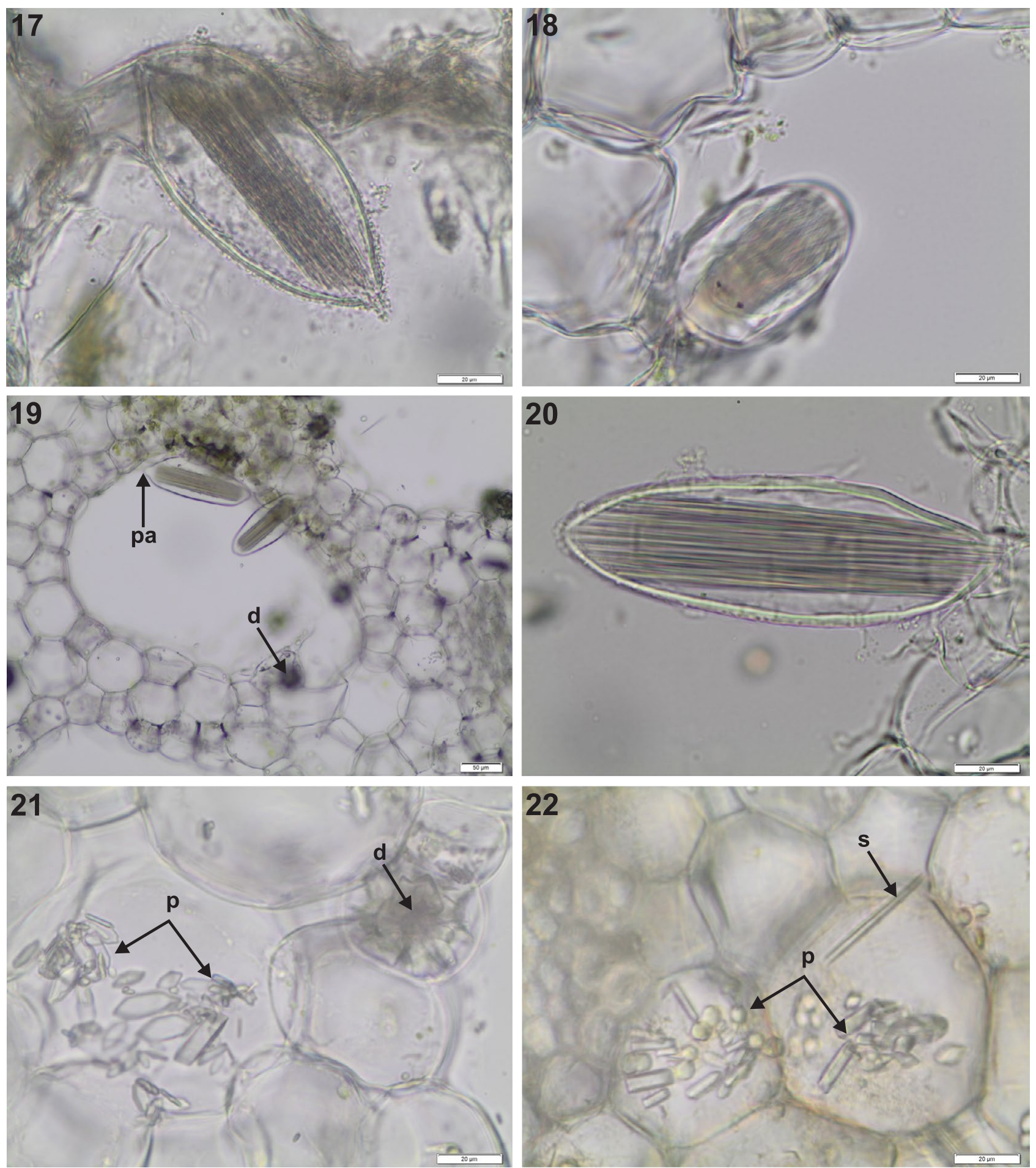

Figs 17-22. Calcium oxalate crystals in the transverse section of petiole. 17 - P. angustisectum, 18 - P. lacerum, 19-20 - P. pinnatifidum, 21 - P. domesticum, 22 - P. lacerum ( $d$ - druse, $p$ - prismatic crystals, $p a$ - papillae, $s-$ styloid)

des within the bundle are oriented in the same direction (Figs 1-5, 10-15, 19-20), or they are obliquely overlapping bundles in P. bipinnatifidum (Figs 6-8), $P$. surinamense (Fig. 9), P. microstictum (Figs 15-16) and P. lacerum (Fig. 18).

If present, raphides are found infrequently (Table 3 ) and they are suspended across the aerenchyma from 1 to 4, e.g. in P. bipinnatifidum (Fig. 1) or 1-3 in P. cordatum and P. pinnatifidum (Fig. 19), or one in the air cavity, simple in the chlorenchyma tissue in P. ornatum (Fig. 11) and in parenchyma cells (Fig. 9). The greatest number of raphides (Table 3 ) was observed in the transverse section of petioles in $P$. bipinnatifidum (11-27), P. cordatum (8-21) and in $P$. pinnatifidum (10-20). Raphides vary in size and shape (Table 3). In biforine-shaped raphides papillae are found one (Figs 1, 2, 10, 12-13, 19) or both ends (Figs. 3,14 ). The thickness of the cell walls is $>2$ 
$\mu \mathrm{m}$. The length of biforine-shaped raphides ranges from 107.4 (P. surinamense) to $170.8 \mu \mathrm{m}$ (P. anguisectum), while their width ranges from 34.7 (P. ornatum) to $50.8 \mu \mathrm{m}$ (P. squamniferum). The length to width ratio in raphides falls within the 2.3 to 3.8 range (Table 3 ) and all idioblasts are packed within single crystal bundles. The length of crystal packets ranges from 68.2 to $96.5 \mu \mathrm{m}$ (P. bipinnatifidum) and their width is from 17.4 (P. cordatum) to $29.1 \mu \mathrm{m}$ (P. bipinnatifidum), while the close-packed ratio of cell length to crystal length is 1.52. In spindle-shaped raphides the ends are rounded and the cell walls is $<2 \mu \mathrm{m}$ in thickness. The length of spindle-shaped raphides ranges from 59.8 (P. microstictum) to $152.7 \mu \mathrm{m}$ (P. bipennifolium) and the width ranges from 32.7 (P. domesticum) to $50.8 \mu \mathrm{m}$ (P. pedatum and P. anguisectum). The raphide length to width ratio ranges from 1.4 to 3.6 (Table 3) and all idioblasts contain a single packed crystal. The
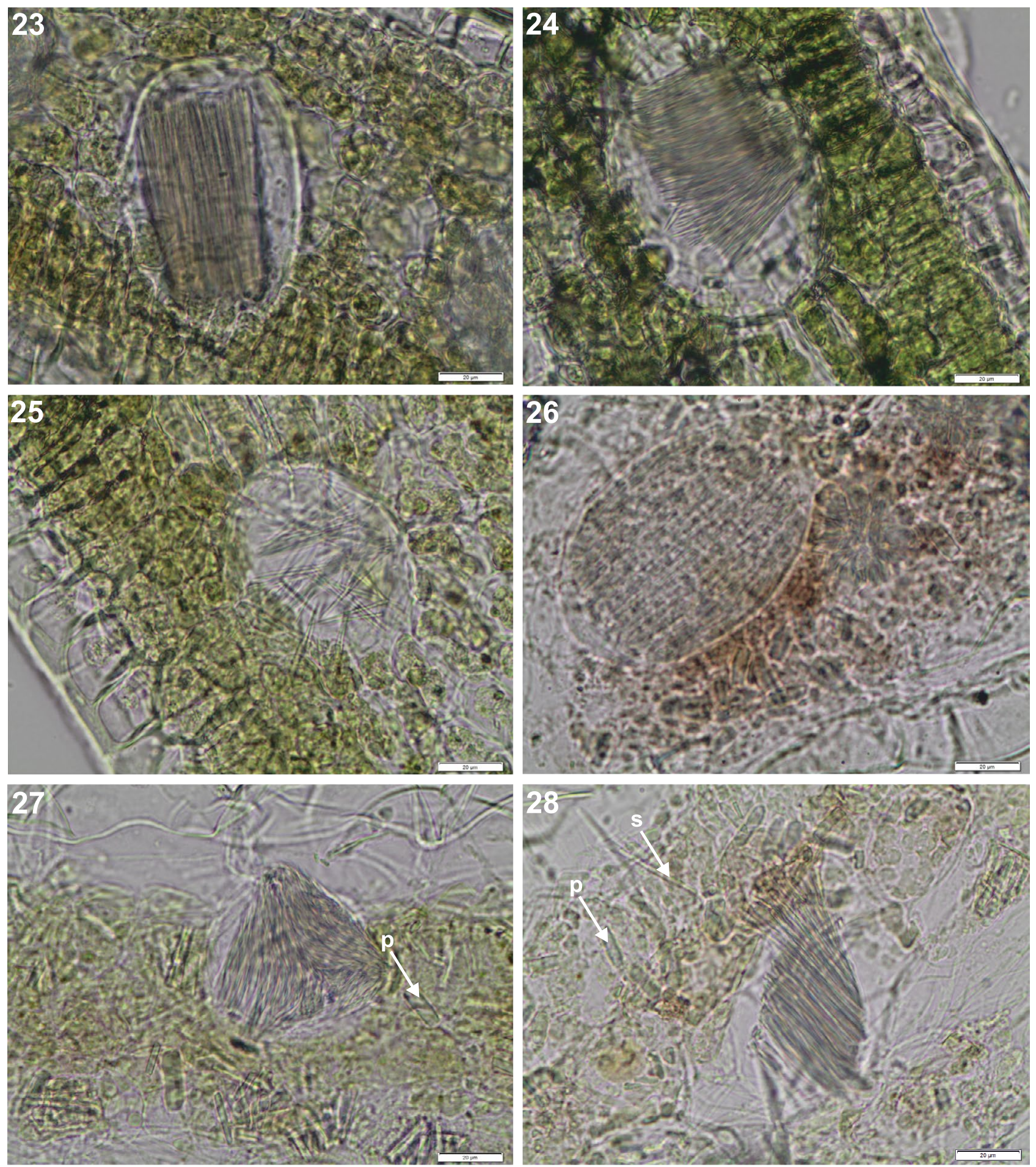

Figs 23-28. Calcium oxalate crystals in the transverse section (T.S.) of lamina: 23-25 - P. bipinnatifidum, 26-28 - P. surinamense ( $p$ - prismatic crystal, $s$ - styloid) 
length of the crystal packet in idioblasts ranges from 49.1 (P. lacerum) to $131.8 \mu \mathrm{m}$ (P. bipennifolium), whereas its width ranges from 15.4 (P. domesticum) to 24.5 $\mu \mathrm{m}$ (P. bipennifolium) and the ratio of cell length to the length of the packed crystal ranges from 1.04 to 1.47.

Wide raphide are spheroidal or oval (Table 3, Fig. 9). The length of wide cell raphides ranges from 27.9 (P. ornatum) to $74.1 \mu \mathrm{m}$ (P. bipinnatifidum), while the width is from 27.8 (P. ornatum) to $67.3 \mu \mathrm{m}$ (P. bipinnatifidum). The idioblast length to width ratio ranges from 1.0 to 1.3 and all idioblasts contain a single crystal packet. The length of the crystal packet ranges from 19.1 (P. ornatum) to $46.7 \mu \mathrm{m}$ (P. surinamense) and the width is from 12.4 (P. ornatum) to 45.4 $\mu \mathrm{m}$ (P. microstictum), while the ratio of cell length to the length of the crystal packet is from 0.96 to 1.5.

The oblique overlapping raphide are pear- or oval-shaped and they are found in P. bipinnatifidum, $P$.
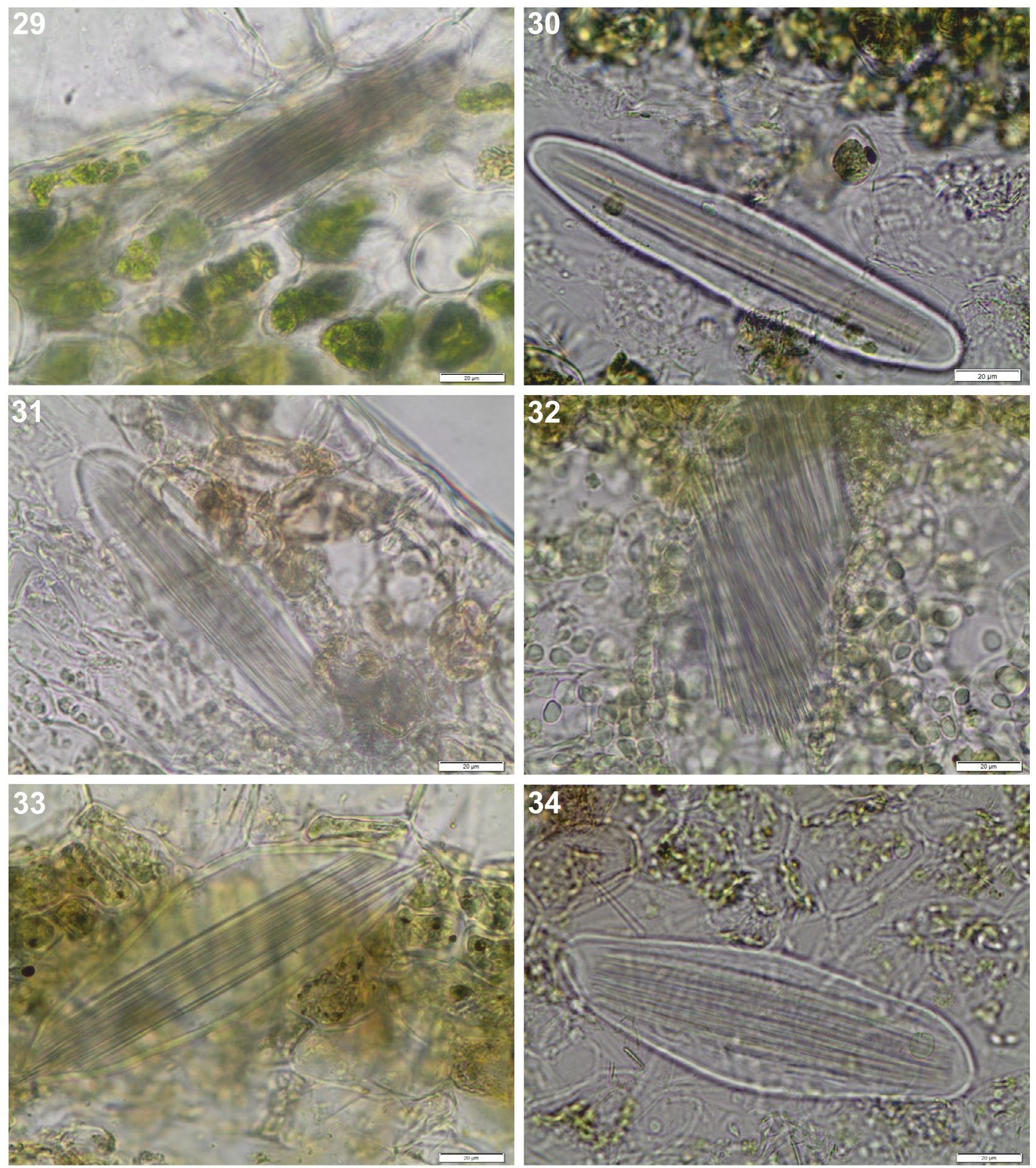

Figs 29-34. Calcium oxalate crystals in the transverse section of lamina 29 - P. crassinervium, 30 - P. melanochrysum, 31-32 - P. domesticum, 33 - P. cordatum, 34 - P. erubescens 
microstictum and P. lacerum (Table 3, Figs 6-8, 15-16, $18)$. In $P$. surinamense wide cells have oblique, overlapping crystals (Fig. 9). The length of the obliquely overlapping raphide ranges from 67.8 (P. microstictum) to $117.3 \mu \mathrm{m}$ (P. bipinnatifidum) and the width from 44.2 (P. microstictum) to $73.7 \mu \mathrm{m}$ (P. bipinnatifi$d u m)$. The raphide length to width ratio ranges from 1.1 to 1.6 and all idioblasts contain a single crystal packet (Table 3 ). The length of needle crystals in these raphides range from 42.7 (P. microstictum) to $75.2 \mu \mathrm{m}$ (P. bipinnatifidum) and their width is from 23.6 (P. microstictum) to $55.7 \mu \mathrm{m}$ (P. bipinnatifidum). The ratio of cell length to the length of the crystal packet ranges from 1.1 (P. surinamense) to 1.6 (P. bipinnatifidum) and the width from 1.1 (P. surinamense) to 1.7 (P. microstictum).

Results presented in this study based on new leaves in relation to a paper by KLIMKo et al. (2014) supply new data concerning the occurrence of raphides in six species: $P$. melanochrysum, $P$. ornatum, $P$. bipennifolium, $P$. imbe, P. martianum and P. lacerum (Table $3)$. Raphides were not observed in P. crassinervium, $P$. hederaceum var. hederaceum or P. erubescens (Table 3), similarly as it was in an earlier study by KцIMKo et al.
(2014). CROAT (1997) stated that in petioles of Philodendron subgenus Philodendron narrow raphide cells occur occasionally and are oriented across aerenchyma partitions with ends pointing into air cavities, or with cells randomly oriented. Our investigations show that in this subgenus wide cells and obliquely overlapping are also found. When comparing species from the subgenera Meconostigma and Pteromischum significant differences were observed in the frequency of raphides in transverse sections of petioles (Table 3). Elongated styloids have pointed ends and they occur singly within cells (Fig. 22). Their length ranges from 15.5 to $74.5 \mu \mathrm{m}$.

Our research shows that in the petioles of subgenus Philodendron styloids are present, which is not cited by CROAT (1997).

The shape of prismatic crystals can be rectangular, rhomboid, hexagonal and square (Figs 21-22) and their size depends on their shape. Small groups of small prismatics are common in the parenchymal tissue.

CALCIUM OXALATE CRYSTALS IN LAMINA (Table 4, Figs 23-38). Cell types may be unmodified with respect to neighboring cell shapes (Fig. 32) or
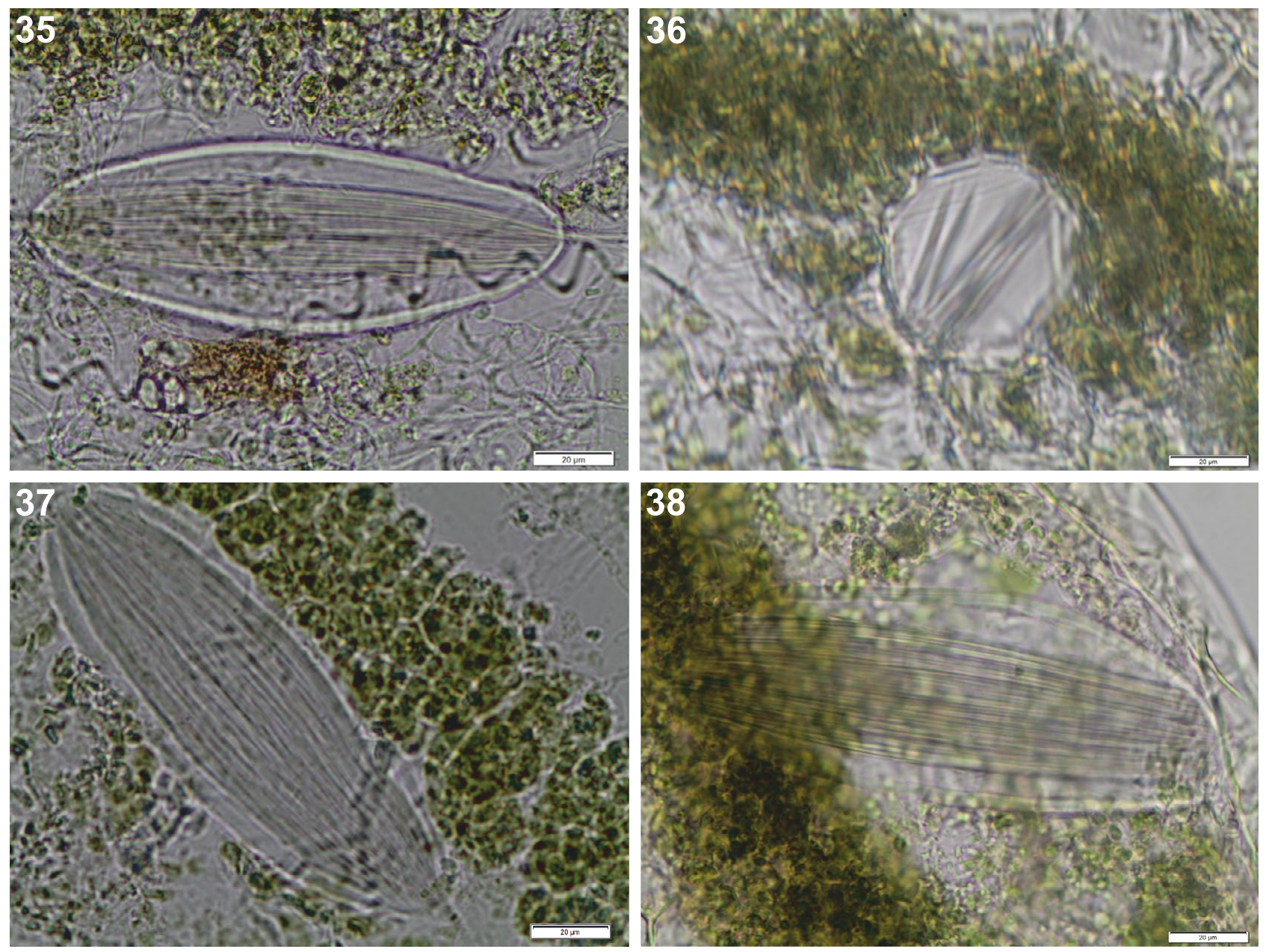

Figs 35-38. Calcium oxalate crystals in the transverse section of lamina: 35 - P. martianum, 36 - P. angustisectum, 37 - P. lacerum, 38 - P. pinnatifidum 
may be idioblastic. which are represented by various raphides (Figs 23-27, 29-31, 33-38), druses (Fig. 26), styloids (Fig. 28) and prismatic crystals (Figs 27, 28). The laminas of Philodendron demonstrate the presence of four distinctive raphide crystal types: thin-walled spindle-shaped cells (Figs 23-27, 2931), biforine-shaped (Figs 33-34), obliquely overlapping crystals (Figs 24, 27, 36) and wide cells (Fig. 26). Raphides are found more often in the spongy mesophyll, across the palisade/spongy mesophyll or in air cavities.

Biforine shaped raphides (Table 4) range from 98.9 to $173.6 \mu \mathrm{m}$ in length (P. ornatum, P. squamiferum, respectively) and from 24 to $59.2 \mu \mathrm{m}$ in width (P. bipennifolium, $P$. squamiferum, respectively). The raphide length to width ratio ranges from 2.9 (P. ornatum) to 5.6 (P. melanochrysum). The ratio of the length of cells (idioblasts) to the length of crystal packets ranges
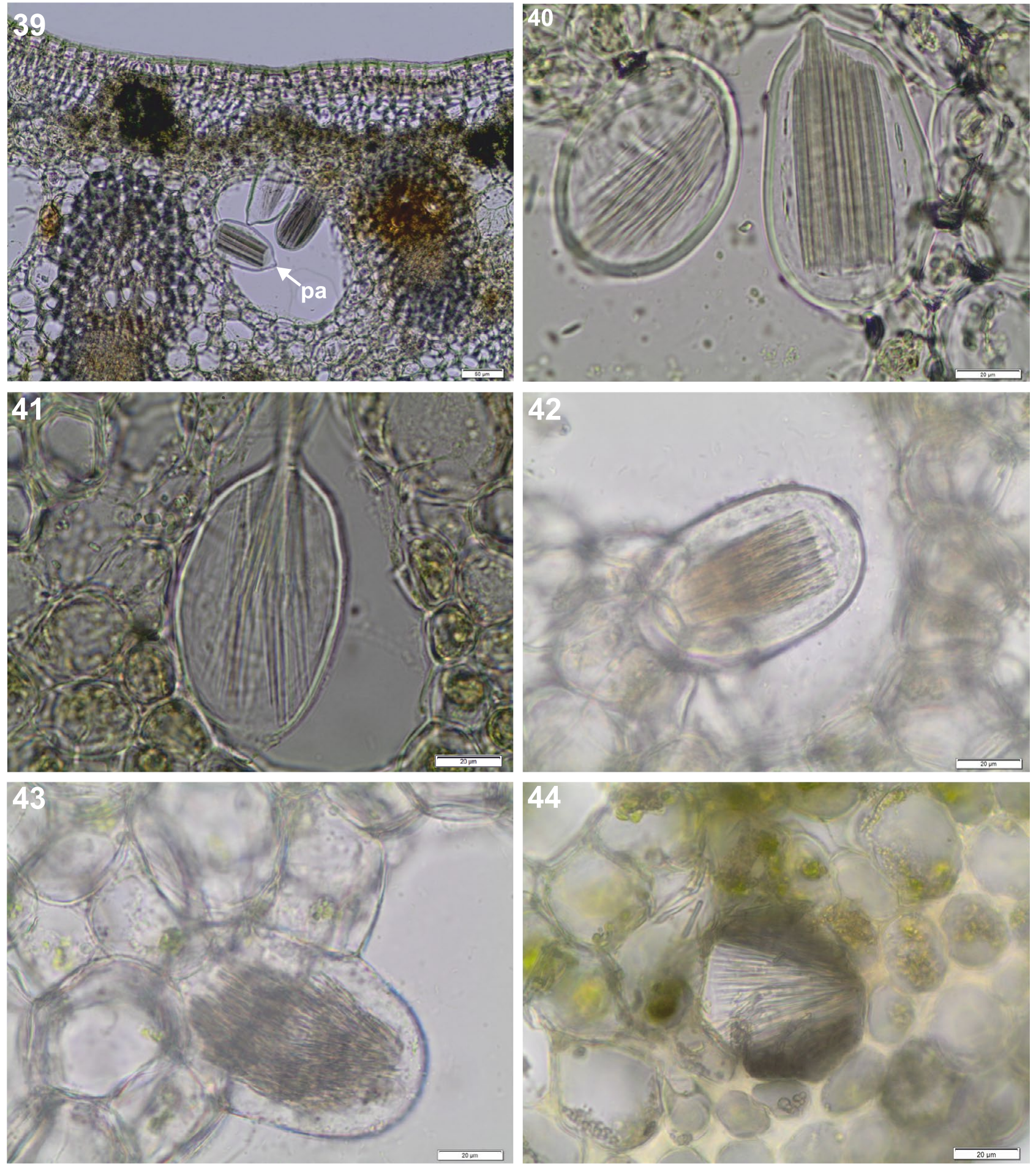

Figs 39-44. Calcium oxalate crystals in the transverse section of midrib: 39-43 - P. bipennifolium, $44-P$. hederaceum var. oxycardium ( $p$ - prismatic crystal, $p a-$ papillae, $s$ - styloid) 

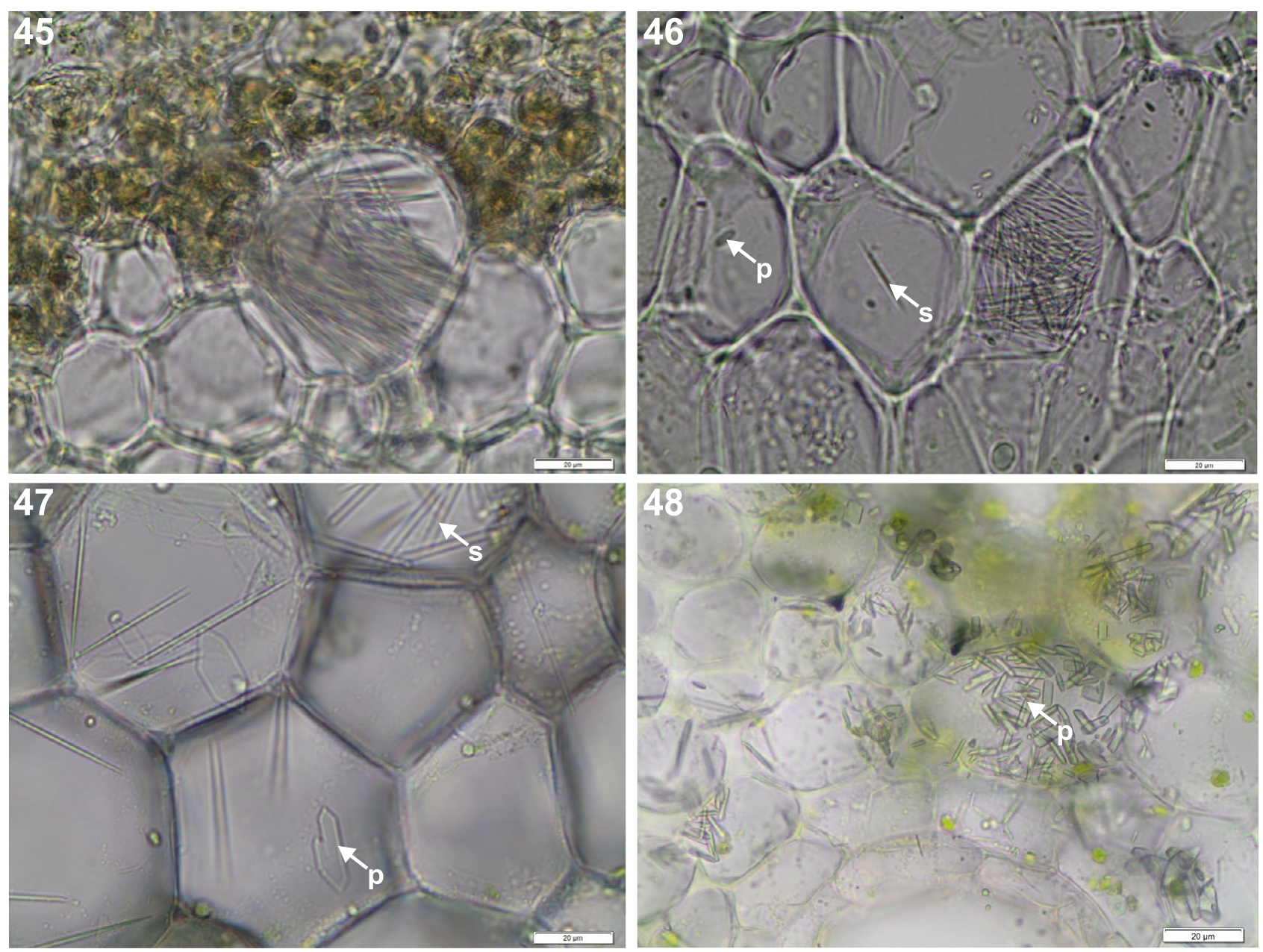

Figs 45-48. Calcium oxalate crystals in the transverse section of midrib: 45 - P. angustisectum, 46 - P. lacerum, 47 - P. ornatum, 48 - P. pinnatifidum ( $p$ - prismatic crystal, $p a$ - papillae, $s$ - styloid)

from 1.1 (P. melanochrysum) to 1.4 (P. bipinnatifidum) and that of the width from 1.3 (P. squamiferum) to 1.8 (P. bipinnatifidum). The length of the spindle-shaped raphides ranges from 64.3 to $154.9 \mu \mathrm{m}$ (P. surinamense, P. melanochrysum, respectively) and from 28 to 58.6 $\mu \mathrm{m}$ in width (P. domesticum, $P$. bipinnatifidum, respectively) (Table 4$)$. The raphide length to width ratio ranges from 1.4 (P. bipinnatifidum) to 4.9 (P. lacerum). The ratio of cell length to crystal packet length ranges from 1.1 (P. ornatum) to 1.3 (P. bipinnatifidum) and that of the width from 1.1 (P. crassinervium) to 2.5 (P. cordatum). The length of wide raphides ranges from 33.1 (P. ornatum) to $95.71 \mu \mathrm{m}$ (P. surinamense) and from 34.1 to $66.1 \mu \mathrm{m}$ (P. ornatum, P. bipinnatifidum, respectively) (Table 4 ). The ratio of raphide length to width ranges from 0.9 (P. ornatum) to 1.5 (P. surinamense). The ratio of the length of idioblasts to the length of crystal packets ranges from 1.1 (P. ornatum) to 1.3 (P. surinamense) and the width from 1.1 (P. surinamense) to 1.5 (P. ornatum).

The length of obliquely overlapping raphides (Table 4) ranges from 65.4 (P. angustisectum) to 101.8 $\mu \mathrm{m}$ (P. bipinnatifidum) and the width from 35.3 ( $P$. surinamense) to $66.4 \mu \mathrm{m}$ (P. bipinnatifidum) (Table 4).
The ratio of the length to the width of raphides ranges from 1.2 ( $P$. angustisectum) to 1.8 (P. surinamense), (Figs 24-25, 27-28, 34, 36). Styloids in laminas are found singly in the ground tissue, e.g. P. surinamense and $P$. erubescens (Figs 28, 34) or in agreggations, e.g. in P. surinamense (Fig. 28), P. ornatum, P. melanochrysum, P. hederaceum, P. domesticum (Fig. 32), P. imbe and $P$. microstictum in the hypodermis and mesophyll. Druses are often coarse and sharp-pointed, in rounded cells in the palisade and spongy tissue partitions (Fig. 26). Druses occur more frequently in both mesophyll types, and rarely in the epidermis, e.g. P. melanochrysum, $P$. hederaceum, $P$. squamiferum and $P$. lacerum (adaxial epidermis). Prismatic crystals were observed in the mesophyll of laminas (Figs 27, 28). Regarding crystals in Philodendron (subgenus Philodendron) CROAT (1997) stated that leaf raphides, if present, are found in single packets in short or elongated cells, ends protruding across partitions into both adjacent air spaces, or in large rounded cells of the upper and lower mesophyll.

CALCIUM OXALATE CRYSTALS IN THE MIDRIB (Figs 39-48) are similar as in petioles and laminas, while the cell types may be unmodified with 
respect to neighbouring cell shapes (Fig. 46) or may be idioblastic which are represented by various raphides (Figs 39-45), druses, styloids (Figs 46-47) and prismatic crystals (Fig. 46-48). More styloids are found in petioles and midribs in comparison to laminas. It should be stressed that styloides are not present in laminas in some species of the family Araceae (Genua \& Hillson 1985, Mantovani \& Pereira 2005). Therefore, the absence or presence of styloids in leaves may be regarded as a taxonomic character.

According to Keating (2004a), spindle-shaped and biforines raphides may be oriented across aerenchyma partitions, or attached by one end and suspended within the air cavity, and our results are consistent with the author's descriptions. The thinwalled spindle-shaped and the biforine types tend to be associated with the aerenchyma having large cavities. No elongated raphides reported by KEATING $(2003,2004 a)$ were observed in P. bipinnatifidum (subg. Meconostigma). According to SAADI \& MONDAL (2011), the size and appearance of calcium oxalate crystals can differ within families, genera and species and these characteristics might be genetically controlled. The frequency of crystals is probably related to the habit, habitat and also the environmental conditions. In our research all plants had a similar habitat, which reduces a majority of environmental/ geographical effects on the occurrence of calcium oxalate crystals.

In conclusion, our study concerning calcium oxalate crystals of selected Philodendron species provide some important new data on the presence and distribution of several distinctive raphide crystal types, druses, styloids, and prisms in terms of their size and shape in petiole and lamina. No elongated raphides reported by KeATING (2004a) were found in P. bipinnatifidum. There is no absolute correlation between the presence and type of calcium oxalate crystals in different subgenera. The taxonomic value of the presence or absence of different calcium oxalate crystals should be studied on a larger number of species.

\section{ACKNOWLEDGEMENTS}

We are grateful to Ilona Wysakowska for her technical assistance and to Wojciech Klimko for his assistance with computer data recording. The authors would like to thank two anonymous reviewers for their suggestions and comments made on an earlier version of the manuscript. The study was partly supported by the Department of Botany, the Poznan University of Life Sciences and the Department of Plant Taxonomy, Adam Mickiewicz University in Poznań.

\section{REFERENCES}

BORCHERT R. (1984): Functional anatomy of the calcium excreting system of Gleditsia triacanthos L. Botanical Gazette 145: 475-482.

Brubaker C.L., Horner H.T. (1989): Development of epidermal crystals in leaflet of Stylosanthes guianensis (Leguminose; Papilionoideae). Canadian Journal of Botany 67: 1664-1670.

Croat T.B. (1997): A revision of Philodendron subgenus Philodendron (Araceae) for Mexico and Central America. Annals of the Missouri Botanical Garden 84: 311-704.

Foster A.S. (1956): Idioblast remarkable examples of cell specialization. Protoplasma 46: 184-193.

Franceschi V.R., Horner H.T. (1980): Calcium oxalate crystals in plants. Botanical Review 96: 361427.

Frey-Wyssuing A. (1981): Crystallography of the two hydrates of crystalline calcium oxalate in plants. American Journal of Botany 68: 130-141.

GenuA J.M., Hillson C.J. (1985): The occurrence, type and location of calcium oxalate crystals in leaves of fourteen species of Araceae. Annals of Botany 56: 351-361.

Gonçalves E.G., Salviani E.R. (2002): New species and changing concepts of Philodendron subgenus Meconostigma (Araceae). Aroideana 25: 3-15.

Govaerts R., Frodin D.G., Bogner J., Boyce P., Cosgriff B., Croat T.B., Gonçalves E.G., Gayum M., Hay A., Hetterschei D.W., Landolt E., Mayo S.J., Murata J., Nguyen D.W., Sakuragui C.M., Singh Y., THOMpson S., ZHU G. (2002): World checklist and bibliography of Araceae (and Acoraceae). Royal Botanic Garden, Kew.

Grayum M.H. (1990): Revision and phylogeny of the Araceae. Annals of the Missouri Botanical Garden 77: 628-697.

Grayum M.H. (1996): Revision of Philodendron subgenus Pteromischum (Araceae) for Pacific and Caribbean tropical America. Systematic Botany 47: $1-233$.

HoRner H.T., WhitMoyer R.E. (1972): Raphide crystal cell development in leaves of Psychtria punctata (Rubiaceae). Journal of Cell Science 11: 339-355.

Keating R.C. (2002): Anatomy of the monocotyledons IX. Acoraceae and Araceae. Clarendon Press, Oxford.

KeAting R.C. (2003): Leaf anatomical characters and their value in understanding morphoclines in Araceae. Botanical Review 68(4): 510-523.

Keating R.C. (2004a): Systematic occurrence of raphide crystals in Araceae. Annals of Missouri Botanical Garden 91, 3: 495-504.

Keating R.C. (2004b): Vegetative anatomical data and its relationship to a revised classification of the genera of Araceae. Annals of the Missouri Botanical Garden 91, 3: 485-494. 
KLimko M., WaWrzyŃsKa M., Wiland-SzymańsKa J. (2014): Comparative leaf morphology and anatomy of some neotropical Philodendron Scott (Araceae) species. Steciana 18(3): 159-171.

Mantovani A., Pereira T.E. (2005): Comparative anatomy of leaf and spathe of nine species of $A n-$ thurium (section Urospadix, subsection Flavescentiviridia) (Araceae) and their diagnostic potential for taxonomy. Rodriguésia 56(88): 145-160.

MaYo S.J. (1988): Aspectos da evolucao e da geografia do genero Philodendron Schott (Araceae). Acta Botanica Brasilica 1(2): 27-40.

MAYO S.J. (1990): History and infrageneric nomenclature of Philodendron (Araceae). Kew Bulletin 45: $37-71$.

Mayo S.J. (1991): A revision of Philodendron subgenus Meconostigma (Araceae). Kew Bulletin 46(4): 601-681.

Mayo S.J., Bogner J., Boyce P.C. (1997): The genera of Araceae. Royal Botanic Gardens, Kew.

Prychid C.J., Rudall P.J. (1999): Calcium oxalate crystals in monocotyledons: a review of their structure and systematics. Annals of Botany 84: 725-739.

SaAdi A.I., Mondal A.K. (2011): Studies on the calcium oxalate crystals in some selected aroids (Araceae) in Eastern India. Advances in Bioresearch 2(1): 134-143.

Sakuragui C.M., MaYo S.J., Zappi D.C. (2005): Taxonomic revision of Brazilian species of Philodendron section Macrobelium. Kew Bulletin, 60: 465-513.

Solereder H, Mayer FJ. (1928): Systematische Anatomie der Monokotyledonen. Verlag von Gebrüder Bornträger Buchhandlung, Berlin, Stuttgart.
Spitzer E., LotT J.N.A. (1982): Protein bodies in umbelliferous seeds. I. Structure. Canadian Journal of Botany 60: 1381-1391.

TURPIN P.J.F. (1836): Observations sur les biforines, organeus nouveaux situés entre les véscicules du tissu cellulaire des feuilles dans un certain nombre d'espèces végétales appartenant à la famille des Aroidées. Annals die Sciences Naturelles, Botanique 2: 5-27.

Wang Z.-Y,. Gould K.S., Patterson K.J. (1994): Structure and development of mucilage-crystal idioblast in the roots of five Actinidia species. International Journal of Plant Sciences 155: 342-439.

Wевв M.A. (1999): Cell-mediated crystallization of calcium oxalate in plants. American Society of Plant Physiologists 11(4): 751-761.

Webb M.A., Arnott H.J. (1982): A survey of calcium oxalate crystals and other mineral inclusions in seeds. Scanning Electron Microscopic 3: 11091113.

ZINDLER-Frank E. (1975): On the formation of the pattern of crystal idioblasts in Canavalia ensiformis DC. VII. Calcium and oxalate content of the leaves in dependence of calcium nutrition. Zeitschrift für Pflanzenphysiologie 77: 80-85.

For citation: Klimko M., WaWRZYŃSKA M., WilAND-SZYMAŃSKA J. (2016): Calcium oxalate crystals in some Philodendron Schott (Araceae) species. Steciana 20(3): 103-116. doi: 10.12657/steciana.020.013 